\title{
Sexually transmitted infection and seafarers: raising awareness on preventing prostitution?
}

\author{
Richard Pougnet ${ }^{1,2,3}$, , Pol Bleunven², Brice Loddé ${ }^{1,2,4} \oplus^{(}$, David Lucas $^{1,2,4} \oplus^{\circ}$, \\ Jean-Dominique Dewitte ${ }^{1,2,3}$, Laurence Pougnet ${ }^{1,5}$ \\ ${ }^{1}$ Société Française de Médecine Maritime (SFMM), France \\ ${ }^{2}$ Centre de Pathologies Professionnelles et Environnementales, CHRU Morvan, Brest, France \\ ${ }^{3}$ Laboratoire d'Etudes et de Recherche en Sociologie (LABERS), EA 3149, Faculté des Lettres et Sciences Humaines, Victor Segalen, \\ Université de Bretagne Occidentale, Brest, France \\ ${ }^{4}$ Optimisation des Régulations Physiologiques (ORPHY), EA 4324, Université de Bretagne Occidentale, Brest, France \\ ${ }^{5}$ Hôpital d'Instruction des Armées, Clermont-Tonnerre, Brest, France
}

According to a literature review studying sexually transmitted infections (STIs) amongst seafarers, $19.5 \%$ of seafarers have had an intercourse with a sex worker [1]. Reported rates range between $2.5 \%$ and $66.0 \%$ depending on the study. As high as these rates might seem, they resemble those of the general French male population, estimated at $15 \%$.

The issue of STIs amongst seafarers is historically linked to prostitution. This became a noticeable matter of concern in the $19^{\text {th }}$ century, when the health and efficiency of British armed forces and navy soldiers was threatened by the spread of STIs, requiring political action to be taken. A series of laws, known as the Contagious Diseases Acts, was introduced in an attempt to submit suspected prostitutes to undergo medical examinations, compelling them to be treated, if needed, in specialised STI hospitals [2].

This law sparked significant controversy, fuelled by a philosopher John Stuart Mill, who disapproved of this project [3]. He perceived the arrest and forced medical check-ups on suspected women as an infringement on personal freedom and an inequality between men and women. Moreover, he expressed his concerns about institutionalizing sex workers' care, which could suggest that the authorities condoned prostitution by making it safer [4].

Nowadays, prostitution practices vary depending on the country. While some choose to enable it, others prohibit seeking a prostitute without penalising the sex workers themselves, and some countries outright ban and punish both sex workers and the clients.

Although the debate on prostitution issues goes beyond the field of maritime medicine, maritime and military doctors should be aware of political, moral, philosophical and religious specificities that may vary from country to country. This would enable them to give relevant advices to seafarers, regarding not only the risk of STIs itself, but also potential fine or jail penalties etc. These physicians should question their role in overall health promotion. Prevention of STIs could also be broadened on preventing prostitution itself. Sex workers are known to be a vulnerable population, threatened by insecurity, violence, drugs, infections, etc. Would it be unrealistic to expect these doctors to prevent seafarers from engaging with sex workers? Scientific literature shows that interaction with sex workers is mainly linked to long distance journeys [1]. Promoting intellectual, leisure or spiritual activities could help in preventing this behaviour [5]. Investigating the reasons driving seafarers to seek intercourse with sex workers might also help in preventing these conducts. It is believed that peer pressure might have a role to play in that regard. Prevention must therefore be collective in order to change mentalities.

\section{REFERENCES}

1. Pougnet R, Pougnet L, Dewitte JD, et al. Sexually transmitted infections in seafarers: 2020's perspectives based on a literature review from 2000-2020. Int Marit Health. 2020; 71(3): 166-173, doi: 10.5603/IMH.2020.0030, indexed in Pubmed: 33001427.

2. Nevins Birkbeck J, Ffolliott N. Contagious Diseases Acts. Br Med J. 1875; 743(1): 430-431.

3. Mill JS. Essays on Equality, Law, and Education. Robson JM (ed.), with an Introduction by S. Collini. Routledge \& Kegan Paul - University of Toronto Press, London \& Toronto 1984.

4. Guillin V. Biopolitique, utilitarisme et libéralisme. Archives de Philosophie. 2010; 73(4): 615, doi: 10.3917/aphi.734.0615.

5. Haglund KA, Fehring RJ. The association of religiosity, sexual education, and parental factors with risky sexual behaviors among adolescents and young adults. J Relig Health. 2010; 49(4): 460-472, doi: 10.1007/s10943-009-9267-5, indexed in Pubmed: 19565334. 